\title{
THE EVOLUTION OF INTER-FIRM RELATIONSHIPS AND IMPACT ON COMMUNICATION NEEDS
}

\author{
Thierry Nagellen ${ }^{1}$, Servane Crave $^{2}$ and Roberto Bolelli ${ }^{3}$ \\ France Telecom R\&D, thierry.nagellen@francetelecom.com \\ ${ }^{2}$ France Telecom $R \& D$, servane.crave@francetelecom.com \\ ${ }^{3}$ CMInternational, $r$.bolelli@cm-intl.com \\ FRANCE
}

This paper presents a new inter-firm relationship typology which helps to characterize the principal forms of such networks in order to assess their potential in terms of communication services needs. Our study is focused on one type of inter-firm relationship: "Open Networks System".

\section{INTRODUCTION}

Organizational long terms trends are leading to resurgence of complex virtual organizations where activities are coordinated through a mix of co-operation and market links. In the past, the management of transactional requirements became internalized to the host organization. Today, the economic reasoning that sponsored the self-sufficient large organization has led to the advance of outsourcing, and introduced new forms of organization such as the extended firm. In their effort to increasingly focus on their core competencies, to benefit from the multiple advantages of various types of cooperative networking structures and to use the new IT solutions in order to relocate some of their business processes, companies have revolutionized the traditional "Fordian" conception of the integrated firm. The large vertically structured corporation is not anymore sufficiently efficient to meet greater cost discipline demands. Flexibility and adaptability have become key management concepts to develop a sustainable competitive advantage, and successful firms apply them in new organizational strategies that put into question many conventional beliefs on organizations and their management. These strategies involve a new and responsive work organization, based on co-operative relations not only within the firm but also in its relations with customers, suppliers and competitors. 


\section{A NEW INTER-FIRM RELATIONSHIP TYPOLOGY}

In 2003, France Telecom has launched a series of studies in order to evaluate the evolutions of inter-firms relationships and its impact on communication needs. In this context a typology has been realized and carried out by the strategy and management consultancy $\mathrm{CM}$ International in collaboration with renowned professor of the French leading business school HEC. This typology, summarized below (figure 1), has been created to characterize and classify inter-firms networks, according to highly discriminating factors. Organizational theory provides a variety of very heterogeneous dimensions that can be used to distinguish between different forms of inter-firm relationships. Often rather descriptive, they are of very unequal analytical value for the purpose of the present paper. The analytical framework we propose is based on four dimensions essentially concerned with the spirit pervading the inter-firm relationship, namely those related to the issues of power and dependency, time and stability, scope and focus, as well as involvement and management control. Mutually largely independent, these criteria take into account the important issues of the internal power balance, the underlying (temporary) intent, the conception of identity and management and control.

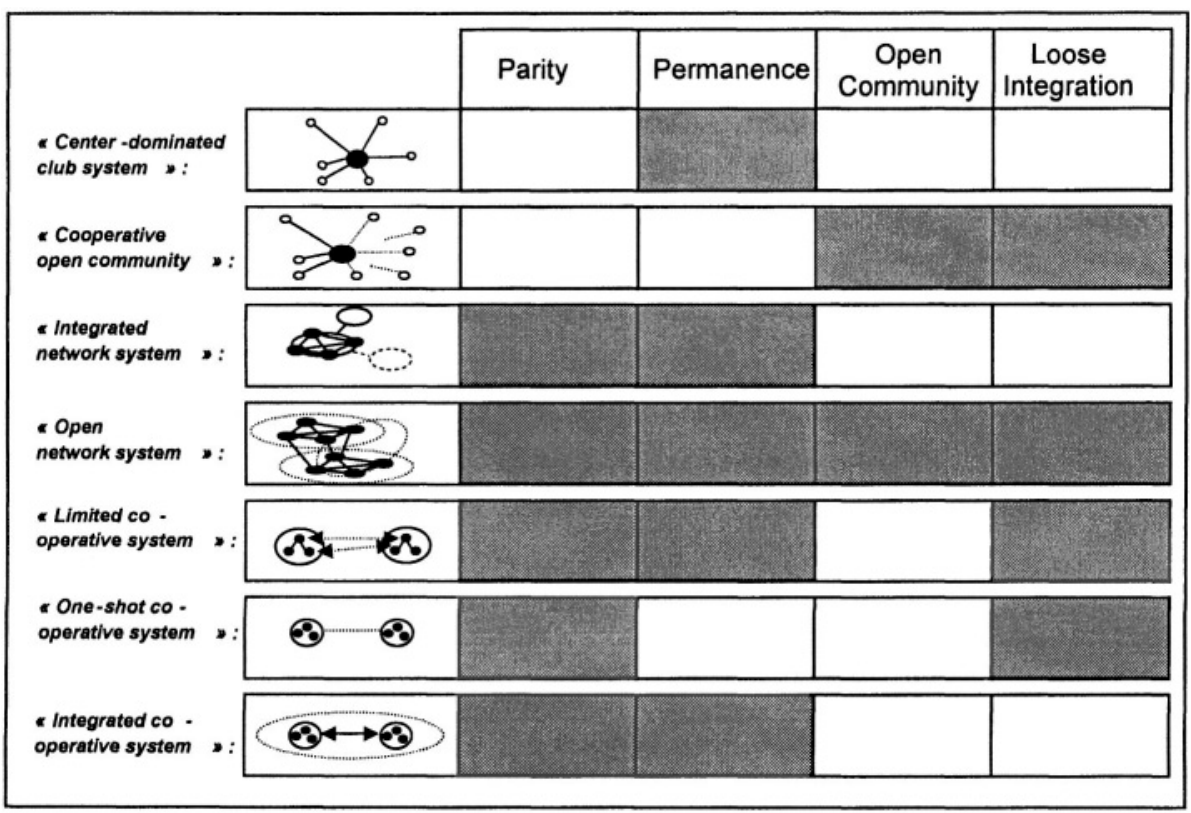

Figure 1- classification into seven different forms of inter-firms relationships 


\section{APPROACH BASED ON INTERMEDIATION FUNCTIONS}

Table 1- associated intermediation services degree of importance

\begin{tabular}{|c|c|c|c|c|c|}
\hline & & \multicolumn{2}{|r|}{ Intermediation } & \multicolumn{2}{|l|}{ functions } \\
\hline Type of network & & Architect & Gatekeeping & Caretaking & $\begin{array}{l}\text { Tech. } \\
\text { Conception }\end{array}$ \\
\hline $\begin{array}{l}\text { Center-dominated } \\
\text { club system }\end{array}$ & & $\begin{array}{l}\text { Business Process } \\
\text { integration } 8 \\
\text { performance } \\
\text { standards }\end{array}$ & $\begin{array}{l}\text { Central Actor } \\
\text { Selection }\end{array}$ & $\begin{array}{l}\text { Animation \& } \\
\text { organizational } \\
\text { learning }\end{array}$ & $\begin{array}{l}\text { Center- } \\
\text { periphery }\end{array}$ \\
\hline $\begin{array}{l}\text { Cooperative open } \\
\text { community }\end{array}$ & & $\begin{array}{l}\text { Flexible Business } \\
\text { Process } \\
\text { integration }\end{array}$ & $\begin{array}{l}\text { Entry marketing } \\
\text { \& Exit } \\
\text { management }\end{array}$ & $\begin{array}{l}\text { Animation \& } \\
\text { evaluation }\end{array}$ & $\begin{array}{l}\text { Open internet- } \\
\text { based platform }\end{array}$ \\
\hline $\begin{array}{l}\text { Integrated network } \\
\text { system }\end{array}$ & & $\begin{array}{l}\text { Mutual and } \\
\text { ongoing } \\
\text { integration }\end{array}$ & $\begin{array}{l}\text { Entry } \\
\text { management }\end{array}$ & $\begin{array}{l}\text { Improvement } \\
\text { trust and } \\
\text { output }\end{array}$ & $\begin{array}{l}\text { Collaborative } \\
\text { tools \& } \\
\text { interoperability }\end{array}$ \\
\hline $\begin{array}{l}\text { Open network } \\
\text { system }\end{array}$ & & $\begin{array}{l}\text { Coordination } \\
\text { Visionary }\end{array}$ & $\begin{array}{l}\text { Entry marketing } \\
\& \text { Exit } \\
\text { management }\end{array}$ & $\begin{array}{l}\text { Animation \& } \\
\text { evaluation }\end{array}$ & $\begin{array}{l}\text { Collaborative } \\
\text { tools \& } \\
\text { interoperability }\end{array}$ \\
\hline $\begin{array}{l}\text { Limited cooperative } \\
\text { system }\end{array}$ & (b) & Procedures & $\begin{array}{l}\text { Information } \\
\text { access }\end{array}$ & $\begin{array}{l}\text { Improvement } \\
\text { trust and } \\
\text { output }\end{array}$ & $\begin{array}{l}\text { Existing } \\
\text { (linternet) } \\
\text { platform }\end{array}$ \\
\hline $\begin{array}{l}\text { One-shot } \\
\text { cooperative system }\end{array}$ & (8) -.... & Leadership & $\begin{array}{l}\text { Entry } \\
\text { management }\end{array}$ & $\begin{array}{l}\text { Closed \& limited } \\
\text { in time }\end{array}$ & External platform \\
\hline $\begin{array}{l}\text { Integrated } \\
\text { cooperative system }\end{array}$ & (34)(2) & Mutual & $\begin{array}{l}\text { Stable } \\
\text { environment }\end{array}$ & $\begin{array}{l}\text { Stable } \\
\text { environment }\end{array}$ & External platform \\
\hline
\end{tabular}

(dark grey $=$ absolutely strategic - grey $=$ important - light grey= relatively unimportant $)$

This table provides a summary of key communication needs and their relative strategic importance to the different types of relationship models. Communication needs associated with different types of inter-firm relationships will be identified in terms of four functions that vary in both nature and intensity depending on the partnership form in question:

\subsection{The architect}

The architect's role is to conceive the inter-firm relationships structure, its objectives, its membership make-up as well as its various operating principles. The architect's function can also be assumed by an internal actor who is able to take in charge the more operational functions relating to gatekeeping and caretaking.

\subsection{The gatekeeper}

Within relatively open network structures, the gatekeeper's role is thereby rather related to the network's marketing (aiming to attract additional external actors) and the management of member firms' exit from the network.

Within closed systems, on the other hand, the gatekeeper's function is much more focused on the selection of new members and the management of the associated 
entry process. Moreover, new organizational forms generally comprise various layers of partnerships and one of the gatekeeper's major tasks is to manage and secure information accessibility according to partner-specific strategic needs and different membership levels.

\subsection{The caretaker}

In charge of the actual management of the existing structure, the caretaker plays an important role as animator and information exchange facilitator. The caretaker is also responsible for the evaluation and improvement of the network process performance. Moreover, the caretaker is in charge of the promotion of interorganizational learning and the promotion of mutual trust.

\subsection{The technical conception}

The integration of different companies' work processes requires the integration of their respective IT systems so that the issue of interoperability becomes of particular importance. The technological dimension is thereby twofold: establishing a common format for the interchange of documents and data, and integrating the applications at the various points along the value chain.

\section{FOCUS ON THE “OPEN NETWORK SYSTEM”}

Even if it's not a new kind of network,, the "open network system" (ONS) features several characteristics (high levels of flexibility, innovative capacities, mutualization of risk, etc.) that makes it appear particularly well adapted to the requirements of increasingly customized, short-lived and knowledge-based market environments.

\subsection{Main characteristics}

The ONS is based on a partial, essentially project-oriented agreement to coordinate independent actors' resources and, by integrating one or more collaborative functions (training, marketing, etc.), to increase the overall value of their offer. In spite of relatively weak levels of integration and focalisation, these ONS are permanent in that they constitute a rather stable base of resources and competences that are being coordinated in order to respond flexibly to the requirements of particular project assignments. Principally made up of small to medium sized, often highly specialized and geographically concentrated companies of roughly equal strength, these networks tend to be relatively loosely integrated and open structures. 


\subsection{Sectors and functions}

Many ONS are geographically concentrated structures with strong industry-specific competence bases. Oyonnax (Plastic Valley), Roubaix-Tourcoing (mail-order and textile industries), or the Italian districts are typical examples. ONS are frequently found in low-tech sectors with relatively short product cycles and the employment ratio between Italian districts and the national total, for example, is highest in the leather industry (66\%), textile and clothing (63\%), glasses (59\%), sofas (58\%), machinery $(49 \%)$ and paper $(41 \%)$. However, ONS can also be found within technological parks, such as Digiport Lille (France) or the Flander's Language Valley (Belgium). Whilst frequently geographically concentrated, ONS can also take on more virtual forms; particularly in sectors featuring already high levels of IT use (graphic design, consultancy, etc.). Consulting Pool AG, a virtual consultancy company, associates a number of independent consultants under a common coordination structure to respond to rapidly changing and increasingly specialized customer demands.

\subsection{Advantages}

The advantages of the ONS are the mutualisation of investment and risk, enhanced quality levels (due to improved product development, organizational learning, access to complementary competence and resource bases, focalisation on core activities), various cost advantages, improved market access and the capacity to flexibly adapt to rapidly changing customer demands. Moreover, its relative stability provides for a context that is very helpful to inter-organizational learning and mutual exchange. And while administrative costs are generally rather low, flexibility is high.

\subsection{Weaknesses}

The risks associated with the loss of strategic autonomy and competence and the underperformance of partner companies are, however, somewhat reduced by lesser degree of mutual focalisation and integration. Higher transaction costs and the sometimes blurred perception by potential customers present more serious difficulties. The handicap of the "integrated network system" related to its multirepresentation is even aggravated in the context of the "open network system". Different cross-ownership arrangements and the elaboration of externally homogeneous entities may often be, where feasible, useful to address the scepticism of customers not at ease in the absence of clear communication and negotiation lines. 


\subsection{Key success factors}

The quality and complementarities of partner companies is a key condition for the network's global success. Appropriate degrees of strategic, resource and organizational fit are very important. Slightly overlapping competence bases constitute thereby no problem and can even be useful for the set-up and development of a positive climate conducive to inter-firm collaboration and learning. Different business processes need to be flexibly integrated according to the requirements of specific project assignments. The issue of leadership and overall coordination is primordial. High levels of trust and commitment represent another key to successful system supplier networking and a strong sense of purpose and shared identity is therefore very important. The strategic coherence of the network has to be permanently monitored.

\subsection{Associated communication needs}

In the absence of hierarchical centralized structures, overall coordination of the ONS is of critical importance. Clear rules and procedures need to be established in order to optimise interaction and cooperation. The architect needs to be ideally a visionary who, by ways of his reputation and authority, succeeds in integrating an intrinsically fluid environment. This function can be assumed by external service providers. In order to attract and interest potential partner companies, the gatekeepers needs to undertake a well-administered ongoing commercial effort whilst, at the same time, managing the exclusion of under-performing partners. Moreover, the need to efficiently structure information accessibility according to different strategic needs and depending to specific partnership levels is primordial. The exclusion of underperforming partners thereby finds its justification in the continuous performance evaluation process provided by the network's caretaker whose role within the ONS is very significant. As the ONS generally features less developed levels of ongoing mutual focalisation and integration, partnership animation has an important function in increasing mutual trust and commitment and to thus facilitate the partners' longterm integration within the network. Whilst often unified in one individual or separate structure, the roles of the gatekeeper and caretaker can be outsourced to external actors. Due to the complexity of coordination and collaboration within the ONS, the issues of network integration, system interoperability and collaborative tools (in the context of more virtual relationship forms) are of high importance. The network's technical conception is thereby largely limited to the object of the interfirm relationship and the utilization of an external platform may be advantageous from a financial point of view whilst being fully adequate (particularly when the object of the collaborative agreement remains limited to the mutualisation of rather peripheral work processes). 


\section{CONCLUSION}

The following table provides a synthetic overview of the study led in 2003 and enhances the key success factors that are associated with the different types of interfirm relationships:

Table 2- key success factors of each kind of typology

\begin{tabular}{|c|c|}
\hline Type of inter-firm relationship & Key success factors \\
\hline Center-dominated star system & $\begin{array}{c}\text { Coordination and control } \\
\text { Business process integration \& collaborative tools } \\
\text { Center-periphery balance }\end{array}$ \\
\hline Center-dominated open community & $\begin{array}{c}\text { Entry marketing \& exit management } \\
\text { Control } \\
\text { Animation }\end{array}$ \\
\hline Integrated network system & $\begin{array}{l}\text { Leadership } \\
\text { Mutual trust and commitment } \\
\text { Shared sense of purpose } \\
\text { Ongoing performance measurement }\end{array}$ \\
\hline Open network system & $\begin{array}{l}\text { Flexible business process integration } \\
\text { Leadership and coordination } \\
\text { Trust and commitment } \\
\text { Animation } \\
\text { Strategic coherence }\end{array}$ \\
\hline Limited cooperative system & $\begin{array}{l}\text { Collaborative tools } \\
\text { Coordination } \\
\text { Performance measurement }\end{array}$ \\
\hline One-shot cooperative system & $\begin{array}{c}\text { Leadership } \\
\text { Operational procedures } \\
\text { Input coordination }\end{array}$ \\
\hline Integrated cooperative system & $\begin{array}{c}\text { Strategic fit } \\
\text { Intercultural sensitivity }\end{array}$ \\
\hline
\end{tabular}

As far as associated communication needs are concerned, one can conclude that:

- the relative importance of IT interoperability, collaborative tools and realtime information access is directly related to the degree of business process integration and inter-firm collaboration,

- the promotion of trust and commitment is absolutely crucial in the context of more open network structures.

"Open Networks System" appears as one of the most promising targets in terms of intermediation service needs even if access to these markets is more difficult than for the centered ones. (since they are characterized by the absence of a dominant central actor)

Therefore, an industrial company must easily identify the Architect and the Technical functions in order to act as Gatekeeper and Caretaker.

Understanding and forecasting the creation of such forms of networks gives to France Telecom a sustainable competitive advantage. 
2003 study results combine the reviewing of standards theories and this analysis of existing case studies.

Next step for France Telecom in 2004 is to follow a more empirical approach through an in depth analysis of such forms of french virtual organizations.

\section{REFERENCES}

1. Bahrami H., "The emerging flexible organization", California Management Review, Summer 1992.

2. Barthélemy J., "Stratégies d'externalisation", Dunod Paris, 2001.

3. Baudry B., « L'économie des relations interentreprises», La Découverte Paris, 1995.

4. Bellier S et al., « Le e-mnagement - vers l'entreprise virtuelle », Liaisons Paris, 2002.

5. Biggiero L., "Self-organizing processes in building entrepreneurial networks", Human Systems Management, Vol 20 Issue 3,2001.

6. Chen Yuh-Min \& Liang Ming-Wu, "Design and implementation of a collaborative engineering information system", International Journal of Computer Integrated Manufacturing, Vol $13 \mathrm{~N}^{\circ} 1$, 2000.

7. Daniels K., et al., "Teleworking, in : Journal of Management Studies", Vol 38 Issue 8, Dec 2001

8. Datamonitor, "Customer Relationship Outsourcing in Europe", Datamonitor New York, 2002

9. Dubar C., «L'appartenance professionnelle a-t-elle encore un sens? », Problèmes Economiques, November 1994

10. Ebers M.(ed.), "The formation of inter-organizational networks", Oxford University Press, Oxford, 1999

11. Frery F., «Benetton ou l'entreprise virtuelle », Vuibert, Paris, 1999

12. Grant R., "Towards a knowledge-based theory of the firm », Strategic Management Journal, $\mathrm{N}^{\circ} 17,1996$

13. Grant R. «Prospering in dynamically-competitive environments », Organization Science, N7(4), 1996

14. Klein B. et al., "Vertical integration, appropriable rents and the competitive contracting process", Journal of Law and Economics, $\mathrm{N}^{\circ} 21,1978$

15. Malon T. \& Yates J., "Electronic markets and electronic hierarchies", ACM, June 1987

16. MARKESS International, «Les prestataires de services sur le marché de l'e-business», Paris, 2001

17. Martinez M.T., et al., "Virtual Enterprise - organisation, evolution and control", International Journal of Production Economics, 2001

18. Mathews John, "The governance of inter-organisational networks", Corporate Governance, Vol 2 $\mathrm{N}^{\circ} 1$, Jan 1994

19. Naulleau G., Guth J.P., "Du partenariat à l'entreprise étendue », Gérer et Comprendre, Sept 2000

20. Nohria N., "Global strategic linkages and industry structure », Strategic Management Journal, $\mathrm{N}^{\circ} 12,1991$

21. Pyke F. \& Becattini G. (eds.), "Industrial districts and inter-firm cooperation in Italy", International Institute for Labour Studies, 1990

22. Powell W., "Neither market nor hierarchy", B.Staw \& L.Cummings (eds.), Research in Organizational Behaviour, 1990

23. Quelin B., "Learning more by learning together", Global Business, London, 1998

24. Quélin B. \& Barthélemy J., «L'externalisation stratégique », Les Echos, 6/12/2000

25. Reed K.\& Blunsdon B., "Organizational flexibility", The International Journal of Human Resource Management, June 1998

26. Sandkuhl K. \& Fuchs-Kittowski F., "Telecooperation in decentralized organizations", Behaviour \& Information Technology, Vol $18 \mathrm{~N}^{\circ} 5,1999$

27. Tuunainen V. "Opportunities of effective integration of EDI for small businesses", Information \& Management, $\mathrm{N}^{\circ} 34,1998$

28. Unterberg C. E. "Business Process Outsourcing”, New York, 2001. 